\title{
PENGARUH KONSENTRASI SERBUK EKSTRAK DAUN KELOR (Moringa Oliefera Lam) DAN TINGKAT KEHALUSAN BAHAN TERHADAP KARAKTERISTIK MINUMAN INSTAN SERBUK KACANG HIJAU (Vigna radiata $L$ )
}

\author{
Hasnelly \\ Neneng Suliasih \\ Moaziah Sarah Nurlinda \\ Program Studi Teknologi Pangan, Fakultas Teknik, Universitas Pasundan, Jl. Dr.Setiabudi No 93, \\ Bandung, 40153, Indonesia \\ Email: hasnelly@unpas.ac.id
}

\begin{abstract}
The purpose of this research to study the effect of the concentration of Moringa leaf powder extract and degree of fineness of materials on the instant beverage powder green beans. This research uses experimental design factorial $3 \times 3$ in ranangan randomized (RAK) in a repeat 3 times, where the factors include: the effect of the concentration of pollen extract of leaves of Moringa (K), which consists of three levels, namely k1 (5\%), k2 (10\%), k3 (15\%) and the degree of fineness of the material (T), which consists of three levels: $\mathrm{t} 1$ (60mesh), $\mathrm{t} 2$ (80mesh), $\mathrm{t} 3$ (100mesh). The response in this study is a chemical response, ie protein content, moisture content. Physical response that total dissolved solids (TSS). Response organoleptic including color, aroma, taste, and consistency and test the antioxidant activity in the selected sample.Moringa leaf powder extract concentration significantly affected the water content of the instant beverage powder green beans. Degree of fineness of materials significantly affect total soluble solid instant beverage powder green beans. The interaction between the concentration of Moringa leaf powder extract and degree of fineness of materials does not affect the organoleptic tests include color, flavor, aroma, consistency, and chemical responses include water content, protein content and physical response that total dissolved solids in the instant beverage powder green beansBased on the chemical analysis and fisica analysis showed that the treatment was selected on the instant beverage powder green beans are $\mathrm{k} 3 \mathrm{t} 3$ concentration of Moringa leaf powder extract $(15 \%)$ and the degree of fineness of materials (100mesh) with a total value of $5.87^{\circ}$ Brix dissolved solids, water content of $8.18 \%$, protein content $20,34 \%$ and amounted to $186014 \mathrm{ppm}$ antioxidant activity.
\end{abstract}

Keywords : Moringa leaves, green beans, instant drinks.

\section{Pendahuluan}

Minuman instan berupa bubuk merupakan produk olahan pangan yang berbentuk serbuk, mudah larut di air, praktis dalam penyajian dan memiliki luas permukaan yang besar (Christiani,2014). Bahan baku pada minuman instan biasanya seperti serelia, tetapi beberapa jenis produk minuman instan yang berada di pasaran seperti serbuk teh, serbuk minuman tradisional seperti rempah-rempah (Asri, 2013).

Menurut Standar Nasional Indonesia (SNI) 014320-1996, serbuk minuman tradisional adalah produk bahan minuman berbentuk serbuk atau granula yang dibuat dari campuran gula dan rempah-rempah dengan atau tanpa tambahan makanan yang diizinkan. Menurut standar mutu serbuk minuman tradisional keadaan warna normal bau dan rasa normal, khas rempah, kadar air pada minuman serbuk tradisional maksimal 3\% dan kadar abu maksimal 1,5\%.

Pangan fungsional merupakan makanan atau minuman yang mengandung bahan-bahan yang dapat meningkatkan status kesehatan dan mencegah timbulnya penyakit tertentu. Salah satu komponen bagi tubuh adalah antioksidan. Asupan antioksidan setiap hari dapat mengurangi peluang munculnya gelaja penyakit degeneratif dan mampu memperlambat penuaan (Aisyah, 2009).

Minuman instan serbuk ekstrak daun kelor dan serbuk kacang hijau akan memperbanyak diversifikasi untuk produk minuman instan, dengan adanya penambahan serbuk ekstrak daun kelor akan meningkatkan nilai gizi dan memiliki antioksidan yang tinggi, dimana dengan menggunakan serbuk kacang hijau pun akan mengurangi penggunaan gandum yang di impor dari Negara lain.

Moringa oleifera Lam (sinonim : Moringa pterygosperma Gaertner) merupakan nama latin dari tanaman kelor. Daun kelor juga memiliki zat antioksidan antara lain sitosterol dan glukopyraniside. Manfaat dari daun kelor antara lain anti peradangan, hepatitis, mempelancar buang air kecil, anti alergi dan 
dapat meningkatkan produksi air susu ibu. Daun kelor memiliki rasa yang hambar dan mempunyai aroma yang kurang baik, tetapi daun kelor dapat menjadi alternative sumber antioksidan yang berpotensi untuk dijadikan serbuk. Serbuk daun kelor memiliki zat hypotensif, antikanker, dan antibatkerial (Krisnandi, 2015).

Kacang hijau (Vigna radiata L.) merupakan salah satu komoditas tanaman kacang-kacangan yang memiliki kandungan protein yang cukup tinggi sebesar $22 \%$ dan merupakan mineral penting antara lain kalsium dan fosfor, sedangkan kandungan lemaknya merupakan asam lemak tak jenuh. Tanaman ini mengandung zat-zat gizi, antara lain : amylum, protein, besi, belerang, kalsium, minyak lemak, mangan, magnesium, niasin, vitamin (B1, A, E) dan karbohidrat. Manfaat lain dari tanaman ini adalah dapat melancarkan buang air besar dan digunakan untuk pengobatan (Musyair, 2014).

Sari kacang hijau biasa disebut juga susu kacang hijau karena berupa cairan yang terbuat dari ekstrak kacang hijau sekitar $70 \%$ serta bahan penunjang lainnya seperti gula pasir, garam, dan jahe (Muradmaulana, 2014). Kombinasi ekstrak serbuk daun kelor dan serbuk kacang hijau menjadi minuman instan yang mengandung protein tinggi.

Berdasarkan latar belakang diatas dapat diketahui identifikasi masalahnya sebagai berikut :

1. Bagaimana pengaruh konsentrasi serbuk ekstrak daun kelor (Moringa oleifera Lam) terhadap karakteristik minuman instan serbuk kacang hijau?

2. Bagaimana pengaruh tingkat kehalusan bahan terhadap karakteristik minuman instan serbuk kacang hijau?

3. Bagaimana interaksi antara konsentrasi serbuk ekstrak daun kelor dan tingkat kehalusan bahan berpengaruh terhadap karakteristik minuman instan serbuk kacang hijau?

Maksud penelitiaan ini adalah untuk memberikan informasi kepada masyarakat mengenai pemanfaatan daun kelor yang dapat dikembangkan menjadi produk minuman instan.

Tujuan dari penelitian ini adalah untuk memperoleh produk minuman fungsional dan diharpkan sebagai produk pangan yang memiliki khasiat bagi tubuh.

Manfaat dari penelitian ini yaitu :

1. Dapat meningkatkan nilai ekonomis dan daya guna tanaman kelor yang memiliki banyak kandungan gizi serta produk olahannya.

2. Diharapkan dengan penelitian ini dapat memberikan informasi mengenai diversifikasi olahan pagan daun kelor dan kacang hijau.

Berdasarkan pemaparan di atas, maka dapat ditarik hipotesis dalam penelitian ini yaitu bahwa diduga konsentrasiserbuk ekstrak daun kelor, serbuk kacang hijau dan tingkat kehalusan pada bahan berpengaruh

\section{Metodologi Penelitian}

Penelitian pendahuluan yang akan dilakukan adalah yang pertama memilih formula dari minuman instan serbuk ekstrak daun kelor dengan serbuk kacang hijau dengan repon uji organoleptik dengan atribut warna, aroma, rasa oleh 30 orang panelis dengan kriteria penilaian tertentu. Hasil penelitian dikumpulkan dan dimasukkan kedalam formulir pengisian, selanjutnya data tersebut dapat diolah secara statistik.

Penelitian yang kedua yaitu analisis serbuk ekstrak daun kelor, analisis filtrat daun kelor, analisis serbuk kacang hijau, analisis serbuk jahe dengan respon analisis kadar air terhadap serbuk kacang hijau, serbuk jahe dan serbuk ekstrak daun kelor dengan metode gravimetri, analisis kadar protein untuk filtrat daun kelor dengan metode formol.

Penelitian utama ini merupakan lanjutan dari penelitian pendahuluan yaitu menentukan konsentrasi serbuk ekstrak daun dan tingkat kehalusan terhadap karakteristik minuman instan serbuk kacang hijau.

Rancangan Perlakuan yang akan dicobakan pada penelitian utama terdiri dari 2 (dua) faktor, yaitu Konsentrasi serbuk ekstrak daun kelor $(\mathrm{K})$ terdiri dari 3 taraf yaitu : $\left(\mathrm{k}_{1} ;(5 \%), \mathrm{k}_{2}(10 \%), \mathrm{k}_{3}:(15 \%)\right)$. Faktor ke dua Tingkat kehalusan bahan (T) terdiri dari tiga taraf yaitu ( $\mathrm{t}_{1}: 60$ mesh, $\mathrm{t}_{2}: 80$ mesh, $\mathrm{t}_{3}: 100$ mesh).

Rancangan percobaan yang dilakukan adalah Rancangan Acak Kelompok (RAK) dengan pola faktorial 3 x 3 dimana masing-masing rancangan terdiri dari 2 (dua) faktor dengan 3 (tiga) kali ulangan, sehingga didapatkan 27 satuan percobaan.

Respon Fisik yang dilakukan pada minuman instan serbuk ekstrak daun kelor dan serbuk kacang hijau adalah penentuan padatan terlarut (TSS) metode refraktrometer .Respon Kimia yang dilakukan pada pembuatan minuman instan serbuk ekstrak daun kelor dan serbuk kacang hijau adalah penentuan kadar protein dengan menggunakan metode kjedhal (AOAC,2005), kadar air menggunakan metode gravimetric (AOAC,2005), dan kadar antioksidan dengan metode DPPH pada produk terpilih. Respon organoleptik dilakukan dengan uji penerimaan (preference test) yaitu uji kesukaan (hedonik) (soekarto, 1985). Respon yang diuji meliputi warna, aroma,rasa dan konsistensi. Panelis yang digunakan untuk menguji minuman instan serbuk kacang hijau sebanyak 30 panelis.

\section{Hasil Penelitian}

Penelitan pendahuluan yang dilakukan adalah analisis kadar air pada serbuk ekstrak daun kelor, serbuk kacang hijau, serbuk esktrak jahe dan analisis kadar protein pada filtrat daun kelor serta penentuan formula menggunakan uji organoleptik.

Analisis kadar protein pada filtrate daun kelor dapat dilihat pada tabel 1 . 
Tabel 1. Hasil Analisis Kadar Protein Pada Filtrat Daun Kelor

\begin{tabular}{|c|c|}
\hline Sampel & Kadar Serat Kasar \\
\hline Filtrat Daun kelor & $0,0385 \%$ \\
\hline
\end{tabular}

Fuglie (2010), menyebutkan kandungan kimia

daun kelor per 100 gram dalam komponen protein sebesar 6,8 gram, sedangkan menurut Trisnawati (2015) konsentrat protein daun kelor sebesar 60,34\%, kedua hal tersebut sangat berbeda apabila dilihat pada hasil analisis kadar protein pada filtrat daun kelor, dimana memiliki hasil sebesar $0,0385 \%$ kehilangan banyaknya protein pada filtrat daun kelor dapat disebabkan oleh proses pembuatan filtrat daun kelor.

Kehilangan banyak protein dapat disebabkan karena beberapa proses saat pembuatan filtrat daun kelor, dimana pada tahap 1 dilakukan proses blanching terlebih dahulu, protein tidak tahan terhadap panas dan akan terdenaturasi, pada proses blanching pun kadar air semakin meningkat. Proses maserasi menurut Danang (2011), memiliki kerugian dimana pada proses maserasi tidak terjadi secara sempurna hanya teresktrak sebesar 50\%, hal tersebut yang membuat kadar protein pada filtrat daun kecil kecil. Menurut Danang (2011), selama proses evaporasi dapat terjadi perubahanperubahan pada bahan, baik yang mengutungkan maupun yang merugikan. Perubahan-perubahan yang terjadi antara lain perubahan viskositas, kehilangan aroma, kerusakan komponen gizi, kecilnya hasil filtrat daun kelor dapat disebabkan dari faktor-faktor tersebut. Besarnya suhu dan tekanan evaporator sangat berpengaruh terhadap proses penguapan cairan. Semakin tinggi maka semakin cepat proses evaporasi, tetapi dapat menyebabkan kerusakan-kerusakan yang dapat menurukan kualitas bahan (Danang, 2011).

Analisis Kadar Air pada serbuk ekstrak daun kelor, serbuk ekstrak jahe, serbuk kacang hijau dapat dilihat pada tabel 2 .

Tabel 2. Kadar Air Pada Serbuk Ekstrak Daun Kelor, Serbuk Ekstrak Jahe, Dan Serbuk Kacang Hijau.

\begin{tabular}{|c|c|}
\hline Bahan & Kadar Air (\%) \\
\hline Serbuk Ekstrak Daun Kelor & $11 \pm 0,70$ \\
\hline Serbuk Kacang Hijau & $8,5 \pm 0,35$ \\
\hline Serbuk Ekstrak Jahe & $8 \pm 0,70$ \\
\hline
\end{tabular}

Kadar air merupakan salah satu karakteristik yang sangat penting pada bahan pangan, karena kandungan air pada bahan pangan. Tingginya kadar air pada bahan pangan dapat mengakibatkan mudahnya bakteri, kapang dan khamir untuk berkembang biak (Purnamasari,2011).

Tepung/serbuk kacang hijau menurut SNI 013728-1995 adalah bahan makanan yang diperoleh dari biji tanaman kacang hijau yang sudah dihilangkan kulit arinya dan diolah menjadi tepung, kadar air pada syarat mutu tepung kacang hijau maksimal $10 \%$, sedangkan bila dilihat pada tabel 12 kadar air pada tepung/serbuk kacang hijau sebesar 8,5\% dan masih sesuai dengan SNI 01-3728-1995. Menurut Fadillah 2010, jahe yang dijadikan serbuk untuk digunakan pada setiap produk pangan memiliki kadar air $8-10 \%$, dilihat pada tabel 13 kadar air pada analisis serbuk jahe sebesar $8 \%$ tetapi bila di lihat pada standar minuman instan tradisional dimana kadar air maksimal 3\% (SNI 01-4320-1996), yang dapat diartikan bahwa serbuk jahe yang memiliki kadar air sebesar $8 \%$, serbuk daun kelor yang memiliki kadar air sebesar $11 \%$ dan serbuk kacang hijau memiliki kadar air sebesar $8,5 \%$ tidak sesuai dengan standar minuman instan tradisional, terjadi beberapa faktor yang membuat tidak sesuai salah satunya adalah penyimpanan dan pengemasan yang kurang baik sehingga bahan pangan yang telah menjadi serbuk menyerap kembali udara lembab yang berada disekitar bahan pangan tersebut.

Menurut Iswari (2007), Foam mat drying adalah teknik pengeringan produk berbentuk cair dan peka terhadap panas melalui teknik pembusaan dengan menambahkan zat pembuih. Kelemahan pada proses pengeringan dimana bahan yang mengandung bahan yang dapat mengikat air secara kuat sulit melepaskan airnya meskipun sudah dipanaskan (Iswari,2007). Untuk mempercepat penguapan air serta menghindari terjadinya reaksi yang menyebabkan terbentuknya air ataupun rekasi yang lain karena pemanasan maka dapat dilakukan pemanasan dengan suhu rendah dan tekanan vakum. Dengan demikian akan diperoleh hasil yang lebih mencerminkan kadar air yang sebenernya (Sudarmajdi, 1989).

Penentuan Formula untuk minuman instan serbuk kacang hijau dengan menggunakan uji organoleptik dapat dilihat pada tabel 3.

Tabel 3. Hasil uji organoleptik beberapa formula minuman instan serbuk kacang hijau pada penelitian pendahuluan.

\begin{tabular}{|c|c|c|c|c|}
\hline \multirow{2}{*}{ Formula } & \multicolumn{4}{|c|}{ Atribut } \\
\cline { 2 - 5 } & Wama & Aroma & Rasa & Kosistensi \\
\hline F2 & $4,23 \mathrm{a}$ & $3,33 \mathrm{a}$ & $2,87 \mathrm{a}$ & $3,73 \mathrm{a}$ \\
\hline F1 & $3,90 \mathrm{a}$ & $3,33 \mathrm{a}$ & $3,10 \mathrm{~b}$ & $3,80 \mathrm{a}$ \\
\hline F3 & $4,27 \mathrm{a}$ & $3,47 \mathrm{a}$ & $3,97 \mathrm{c}$ & $3,93 \mathrm{a}$ \\
\hline
\end{tabular}

Keterangan: Setiap huruf yang berbeda menyatakan perbedaan yang nyata pada taraf $5 \%$.

Penelitian utama merupakan penelitian lanjutan dari penelitian pendahuluan. Pada penelitian utama dilakukan pengamatan pada minuman instan serbuk kacang hijau yaitu pengaruh konsentrasi serbuk ekstrak daun kelor dan tingkat kehalusan pada setiap bahan, dengan menggunakan formula terpilih yang diperoleh dari penelitian pendahuluan. Penelitian utama yang dilakukan bertujuan untuk mengetahui pengaruh konsentrasi serbuk ekstrak daun kelor dan tingkat kehalusan bahan terhadap karakteristik minuman instan serbuk kacang hijau, dimana 
konsentrasi serbuk ekstrak daun kelor yaitu 5\%, $10 \%$ dan $15 \%$, serta tingkat kehalusan terhadap bahan yaitu 60mesh, 80mesh dan 100mesh.

Minuman instan yang dihasilkan dilakukan pengujian secara organoleptik untuk mengetahui tingkat kesukaan penerimaan panelis terhadap produk dengan metode uji hedonik dengan parameter yang digunakan yaitu atribut aroma, warna, rasa dan kosistensi dengan 30 panelis. Selanjutnya dilakukan analisis kimia meliputi kadar air dengan metode gravimetri, kadar protein dengan metode kjedhal dilakukan pada 27 sampel, serta dilakukan analisis secara fisik yaitu uji total padatan terlarut pada 27 sampel dan dilakukan analisis aktivitas antioksidan dengan metode DPPH pada sampel terbaik hasil dari uji respon kimia.

\section{Analisis Kimia \\ Kadar air}

Berdasarkan hasil analisis variansi terhadap kadar air minuman instan serbuk kacang hijau dapat diketahui bahwa faktor K (Konsentrasi serbuk ekstrak daun kelor) berpengaruh terhadap kadar air minuman instan serbuk kacang hijau, tetapi faktor $\mathrm{T}$ (tingkat kehalusan bahan) tidak berpengaruh terhadap minuman instan serbuk kacang hijau dan pada faktor KT (Interaksi antara faktor $\mathrm{K}$ dan faktor $\mathrm{T}$ ) tidak berpengaruh terhadap minuman instan serbuk kacang hijau

Tabel 4. Pengaruh faktor K (Konsentrasi Serbuk Ekstrak Daun Kelor) Terhadap Kadar Air Minuman Instan Serbuk Kacang Hijau

\begin{tabular}{|l|c|}
\hline \multicolumn{1}{|c|}{ Perlakuan } & Kadar Air \\
\hline $\mathrm{k} 1=$ Konsentrasi 5\% & $7,71 \pm 0,49 \mathrm{a}$ \\
\hline $\mathrm{k} 2=$ Konsentrasi $10 \%$ & $8,12 \pm 0,28 \mathrm{~b}$ \\
\hline $\mathrm{k} 3=$ Konsetrasi $15 \%$ & $8,29 \pm 0,27 \mathrm{c}$ \\
\hline $\begin{array}{l}\text { Keterangan: Setiap huruf yang berbeda menyatakan perbedaan yang nyata pada } \\
\text { taraf 5\% }\end{array}$
\end{tabular}

Berdasarkan standar yang ditetapkan oleh SNI 01 - 4320 -1996 (Syarat Mutu Minuman Instan Tradisional), nilai kadar pada minuman instan tradisional minimal 3\%. Pengeringan menggunakan tunnel dryer dengan suhu antara $60^{\circ} \mathrm{C}-70{ }^{\circ} \mathrm{C}$. Menurut Estiasih (2009), pengoperasian tunnel drying bersifat kontinyu. Produk yang dikeringkan diletakan dalam rak-rak dan akan dihembuskan udara panas. Arah udara yang dihembuskan dapat berlawanan dengan arah penggerakan produk atau satu arah.

Air yang terdapat dalam masing-masing bahan akan menguap selama pemanasan atau akan menjadi air terikat karena pengaruh dari bahan lain yang ditambahkan. Suhu dan lama pemanasan juga berpengaruh terhadap kadar air, semakin tinggi suhu yang digunakan maka kadar air akan semakin rendah (Fardiaz dkk, 2008).

Foam - mat drying adalah teknik pengeringan bahan berbentuk cair dan peka terhadap panas melalui teknik pembusaan dengan menambahkan zat pembuih. Pengeringan dengan bentuk busa dapat mempercepat proses penguapan air, dan dilakukan pada suhu rendah sehingga tidak merusak jaringan sel, dengan demikian nilai gizi dapat dipertahankan (Aisyah, 2012).

Kadar Protein

Berdasarkan hasil analisis variansi terhadap kadar protein minuman instan serbuk kacang hijau dapat diketahui bahwa faktor K (Konsentrasi serbuk ekstrak daun kelor), faktor $\mathrm{T}$ (Tingkat kehalusan bahan) dan faktor KT (Interaksi antara faktor K dan faktor $\mathrm{T}$ ) tidak berpengaruh terhadap kadar protein pada minuman instan serbuk kacang hijau.

Pengaruh konsentrasi ekstrak serbuk daun kelor dan tingkat kehalusan bahan tidak berbeda nyata, bila dibandingkan dengan kandungan gizi dari kacang hijau/100gram memiliki kadar protein sebesar $22 \%$, sedangkan hasil kadar protein pada minuman instan serbuk kacang hijau sebesar 19,34\% - 22,11\%. Hal yang membuat tidak berpengaruh terhadap kadar protein pada setiap perlakuan karena adamya penambahan serbuk ekstrak daun kelor yang kecil yaitu $5 \%, 10 \%$ dan $15 \%$, penambahan serbuk ekstrak daun yang kecil tidak membuat kadar protein pada minuman instan serbuk kacang hijau menjadi rendah, dengan adanya penambahan serbuk kacang hijau yang tinggi pada minuman instan serbuk kacang hijau membuat kadar protein tinggi.

Tepung kacang hijau adalah tepung yang didapat dari hasil olahan kacang hijau yang dijadikan tepung yang melalui beberapa proses seperti pencucian, penyangraian, penggilingan dan pengayakan, sehingga dapat menjadi tepung. Keunggulan kacang hijau memiliki nilai protein yang tinggi (22,9 $\mathrm{g} \%)$ setelah kacang tanah dan kacang kedelai (Zaidah, 2011).

Menurut Aswari (2011), semakin tinggi filler yang digunakan semakin kecil kadar protein yang dihasilkan. Hal tersebut dikarenakan adanya bahan tambahan yang mengurangi prosentase protein dalam bahan pangan.

\section{Analisis Fisik}

Total Padatan Terlarut

Berdasarkan hasil analisis variansi terhadap total padatan terlarut pada minuman instan serbuk kacang hijau dapat diketahui bahwa faktor T (Tingkat kehalusan bahan) berpengaruh terhadap total padatan terlarut minuman instan serbuk kacang hijau, tetapi pada faktor K (Konsentrasi serbuk ekstrak daun kelor) tidak berpengaruh terhadap total padatan terlarut pada minuman instan serbuk kacang hijau dan pada faktor KT (Interaksi antara faktor $\mathrm{K}$ dan faktor $\mathrm{T}$ ) tidak 
berpengaruh terhadap total padatan terlarut pada minuma instan serbuk kacang hijau. Berikut hasil analisis kelarutan, dapat dilihat pada Tabel 5.

Tabel 5. Pengaruh faktor T (Tingkat Kehalusan Bahan) Terhadap Total Padatan Terlarut Minuman Instan Serbuk Kacang Hijau.

\begin{tabular}{|l|l|}
\hline Perlakuan & Total Padatan Terlarut \\
\hline $\mathrm{t} 2=(80$ mesh $)$ & $4,99 \pm 0,88^{\circ}$ Brix a \\
\hline $\mathrm{t} \mathrm{l}=(60$ mesh $)$ & $5,66 \pm 0,29^{\circ}$ Brix b \\
\hline $\mathrm{t} \mathrm{B}=(100$ mesh $)$ & $5,79 \pm 0,222^{\circ}$ Brix c \\
\hline
\end{tabular}

\section{Keterangan: Setiap huruf yang berbeda menyatakan perbedaan yang nyata pada $\operatorname{taraf} 5 \%$}

Berdasarkan tabel 5 pengaruh konsentrasi ekstrak daun kelor dan tingkat kehalusan bahan terhadap total padatan terlarut berbeda nyata dengan tingkat kehalusan pada mesh 60 dan mesh 80. Pada mesh 100 total padatan terlarutnya lebih tinggi dibandingkan dengan dengan tingkat kehalusan bahan pada mesh 60 dan mesh 80 hal tersebut karena semakin kecil partikel maka semakin cepat daya larut, semakin halus bubuk tersebut maka kelarutan dalam minuman instan pun akan semakin sempurna (Asri, 2013).

Sifat produk minuman bubuk yang penting adalah kelarutannya, disamping warna, aroma dan cita rasa. Menurut Hermansyah (2012), untuk produk serbuk semakin besar daya larut maka akan semakin baik produk tersebut karena lebih cepat larut saat dicampur dengan air

\section{Respon Organoleptik}

Warna

Berdasarkan hasil analisis variansi terhadap atribut warna dapat diketahui bahwa faktor $\mathrm{K}$ (konsentrasi serbuk ekstrak daun kelor), faktor $\mathrm{T}$ (tingkat kehalusan bahan) dan faktor KT (interaksi antara faktor $\mathrm{k}$ dan faktor $\mathrm{t}$ ) tidak berpengaruh terhadap warna pada karakteristik minuman instan serbuk kacang hijau.

Berdasarkan tingkat kesukaan panelis terhadap warna minuman instan serbuk kacang hijau dapat diketahui melalui grafik berikut :

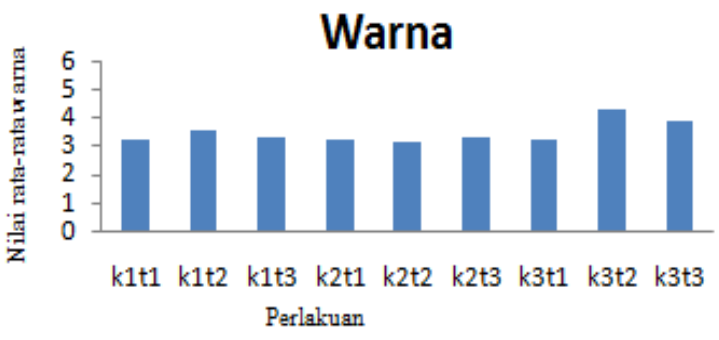

Gambar 1. Nilai rata-rata warna minuman instan serbuk kacang hijau

Berdasarkan gambar 1 dapat dilihat bahwa tidak berbeda nyata berbeda nyata dari atribut warna.
Hal itu disebabkan karena tidak banyak perbedaan warna antar sampel yang disajikan terhadap warna minuman instan serbuk kacang hijau berkisar 3,13 4,32 yaitu agak tidak suka hingga agak suka.

Warna minuman instan serbuk kacang hijau yang dihasilkan adalah warna putih kekuningan, hal ini disebabkan dari formula minuman instan serbuk kacang hijau. Pada formula penambahan serbuk kacang hijau lebih tinggi dibandingkan dengan serbuk ekstrak daun kelor dan serbuk jahe, sehingga membuat faktor konsentrasi serbuk ekstrak daun kelor tidak berpengaruh terhadap minuman instan serbuk kacang hijau, faktor tingkat kehalusan bahan pun tidak berpengaruh terhadap artribut warna karena tingkat kehalusan bahan hanya berbeda dari segi ukuran saja. Warna putih kekuningan yang terbentuk berhubungan dengan reaksi pencoklatan enzimatik dari senyawa fenolik dan reaksi pencoklatan non enzimatik terutaman reaksi Maillard (Wika 2014).

Aroma

Berdasarkan hasil analisis variansi terhadap atribut aroma dapat diketahui bahwa faktor $\mathrm{K}$ (konsentrasi serbuk ekstrak daun kelor), faktor $\mathrm{T}$ (tingkat kehalusan bahan) dan faktor KT (interaksi antara faktor $\mathrm{K}$ dan faktor $\mathrm{T}$ ) tidak berpengaruh terhadap aroma pada karakteristik minuman instan serbuk kacang hijau.

Hasil penelitian menunjukkan bahwa pengamatan terhadap organoleptik dalam hal aroma tidak berbeda nyata pada taraf 5\% dengan nilai ratarata yang tidak signifikan dan tidak terjadi interaksi antara konsentrasi serbuk ekstrak daun kelor dan tingkat kehalusan bahan. Pada setiap penambahan konsentrasi yang berbeda-beda pada serbuk ekstrak daun kelor tidak ada perubahan yang signifikan dikarenakan serbuk ekstrak daun kelor tidak memiliki aroma yang khas atau yang menyengat sehingga hanya tercium aroma dari kacang hijau saja, aroma langu pada kacang hijau dapat dihilangkan dengan adanya perlakuan perendaman, pengupasan kulit dan pemanasan sehingga aroma yang muncul adalah aroma khas kacang hijau.

Berdasarkan tingkat kesukaan panelis terhadap aroma minuman instan serbuk kacang hijau dapat diketahui melalui grafik berikut :

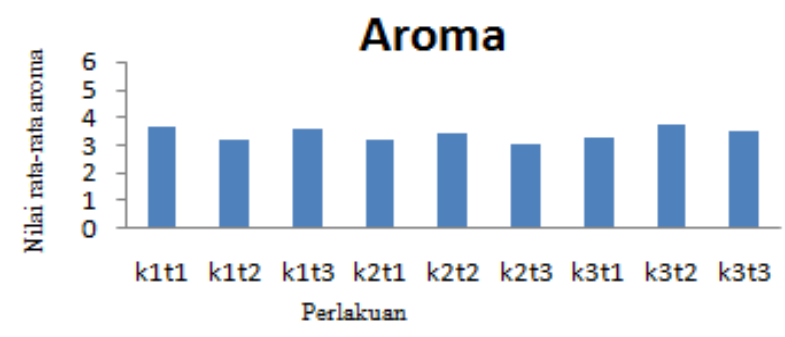

Gambar 2. Nilai rata-rata aroma minuman instan serbuk kacang hijau. 
Rasa

Berdasakan hasil analisis variansi terhadap atribut rasa dapat diketahui bahwa faktor $\mathrm{K}$ (konsentrasi serbuk ekstrak daun kelor), faktor $\mathrm{T}$ (tingkat kehalusan bahan) dan faktor KT (interaksi antara faktor $\mathrm{K}$ dan faktor $\mathrm{T}$ ) tidak berpengaruh terhadap rasa pada karakteristik minuman instan serbuk kacang hijau.

Berdasarkan tingkat kesukaan panelis terhadap rasa minuman instan serbuk kacang hijau dapat diketahui melalui grafik berikut:

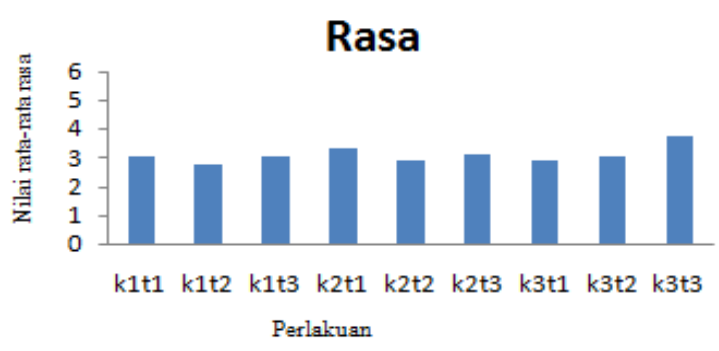

Gambar 3. Nilai rata-rata rasa minuman instan serbuk kacang hijau.

Berdasarkan gambar 3 dapat dilihat bahwa tidak berbeda nyata dalam atribut rasa. Hal itu disebabkan karena rasa yang ditimbulkan tidak memiliki perbedaan, rasa yang dimiliki minuman instan serbuk kacang hijau manis dan rasa khas kacang hijau hal ini disebabkan persentase gula sebesar $15 \%$ dimana formula yang digunakan adalah formula yang sudah terpilih pada penelitian pendahuluan, serbuk ekstrak daun kelor memiliki rasa yang netral sehingga tidak membuat pengaruh terhadap rasa minuman instan serbuk kacang hijau. Pada setiap perlakuan menggunakan formula yang sama sehingga rasa yang dihasilkan pun tidak berbeda nyata.

Berdasarkan hasil penelitian dapat diambil kesimpulan sebagai berikut:

1. Berdasarkan uji organoleptik pada penelitian pendahuluan didapatkan formula terpilih yaitu formula 3 dengan penambahan serbuk kacang hijau 75,5\%, serbuk ekstrak daun kelor 5\%, serbuk ekstrak jahe $3 \%$, garam $1 \%$, gula $15 \%$, dan CMC $0,5 \%$, analisis kadar air pada serbuk kacang hijau sebesar $8,5 \%$, serbuk ekstrak daun kelor sebesar $11 \%$, serbuk ekstrak jahe sebesar $8 \%$, dan analisis kadar protein pada filtrate daun kelor sebesar $0,0385 \%$.

2. Konsentrasi serbuk ekstrak daun kelor berpengaruh nyata terhadap kadar air minuman instan serbuk kacang hijau

3. Tingkat kehalusan bahan berpengaruh nyata terhadap total padatan terlarut minuman instan serbuk kacang hijau.

4. Interaksi antara konsentrasi serbuk ekstrak daun kelor dan tingkat kehalusan bahan tidak berpengaruh terhadap uji organoleptik meliputi warna, rasa, aroma maupun respon kimia meliputi kadar air, kadar protein dan respon fisika yaitu total padatan terlarut pada minuman instan serbuk kacang hijau.

\section{DAFTAR PUSTAKA}

1. Agung Diantoro, Muzaki Rohman, Hapsari Titi Palupi. 2015. Pengaruh Penambahan Ekstrak Daun Kelor (Moringa Oliefera L) Terhadap Kualitas Yogurht. Universitas Yudharta, Pasuruan.

2. Agus Triyono, Nuhaidar Rahman, Yusuf Andriana. 2010. Pengaruh Proporsi Penambahan Air Pengekstrak dan Jumlah Bahan Penstabil Terhadap Karakteristik Susu Kacang Hijau (Phaseolus radiatus L). Balai Besar Teknologi Tepat Guna - LIPI, Subang.

3. Ananda, A, Dwi, 2009. Aktivitas Antioksidan Dan Karakteristik Organoleptik Minuman Fungsional The Hijau (Camellia Sinensis) Rempah Instan. Skripsi Fakultas Pertanian IPB, Bogor.

4. Aisyah Tri Septiana. 2014. Aktivitas Antioksidan Minuman Fungsional dari Irisan Buah Kering Mahkota Dewa. Universitas Jendral Soedriman (UNSOED), Purwokerto.

5. Aisyah Yulianti, Rasdiansyah, Muhaimin. 2015. Pengaruh Pemanasan Terhadap Aktivitas Antioksidan Pada Beberapa Jenis Sayuran. Universitas Syiah Kuala, Darusalam, Banda Aceh.

6. Asiah Nurul, rangkum Sembodo, aji Prasetyaningrum. 2011. Aplikasi Metode Foammat Drying Pada Proses Pengeringan Spirulina. Universitas Diponegoro, Semarang.

7. Asri Ramadina. 2013. Pengaruh Penggunaan Jumlah Gula Terhadap Karakteristik Inderawi Minuman Instan Serbuk Sari Daun Sirsak (Annona Muricata L). Universitas Negeri Semarang, Semarang

8. Astawan, M. 2009. Pangan Fungsional Untuk Kesehatan Yang Optimal. www.kompas.com.

9. Badan Standarisasi Nasional 1995. SIN.01.3728.1995: Syarat Mutu Tepung Kacang Hijau.

10. Badan Standarisasai Nasional 1996. SNI.01.4320.1996: Syarat Mutu Minuman Instan Tradisional.

11. Christiani Tangkeallo, Tri Dewanti Widyaningsih. 2014. Aktivitas Antioksidan Serbuk Minuman Instan Berbasis Miana Kajian Jenis Bahan Baku dan Penambahan Serbuk Jahe. Universitas Brawijaya, Malang.

12. Danang Kumara Hadi. 2011. Evaporasi. Danangkurang-

kerjaan.blogspot.co.id/2011/05/evaporasi.hmtl. (diakses: 19 Oktober 2016).

13. Endang Rahmawati. 2015. Kadar Protein, pH dan Jumlah Bakteri Asam Laktat Yoghurt Susu Sapi 
dengan Variasi Penambahan Sari Daun Kelor dan Lama Fermentasi yang Berbeda. Universitas Muhammadiyah, Surakarta.

14. Erawati. 2012. Uji aktivitas Antioksidan Ekstrak Daun Garciniadeadalanthera Pieree Dengan Metode DPPH (1,1-Difenil Pikrilhidrazil) Dan Identifikasi Golongan Senyawa Kimia Dari Fraksi Paling Aktif. Universitas Indonesia, Depok.

15. Estiasih, T dan Sofia, E. 2009. Stabilitas Antioksidan Bubuk Keluwak (Pangium Edule Reinw) Selama Pengeringan Dan Pemasakan. Jurnal Teknologi PertanianVol. 10 No. 2:115-122

16. Faiz. 2012. Granula Pati. https: //kutankrobek.wordpress.com. diakses : 03 Oktober 2016.

17. Fadillah, M. 2010. Kualitas Organoleptik dan Pertumbuhan Bakteri Pada Susu Pasteurisasi dengan Penambahan Kayu Secang (Caesalpinia sappan L.) Selama Penyimpanan. Universitas Hasanudi, Makasar.

18. Fardiaz, Srikandi, Ratih Dewanti, Slamet Budijarto. 1987. Risalah Seminar : Bahan Tambahan Kimiawi (Food Addictive). Institut Pertanian Bogor, Bogor.

19. Fennema, O.R., M. Karen, and D. B Lund. 1996. Pricinple of Food Science. The AVI Publishing, Connecticut.

20. Fuglie, Lowell J, ed. The Miracle Tree: Moringa oliefera: Natural Nutrition for the Tropics. Training Manual. 2001. Chruch World Service, Dakar, Senegal. www.moringatrees.org/moringa/miracletree.htm. (diakses :12 September 2016).

21. Ismal ibnu. 2014. Total zat padat terlarut. https: //wawasanilmu.wordpress.com. diakses : 03 Oktober 2016.

22. Iswari Kasma. 2007. Kajian Pengolahan Bubuk Instan Wortel Dengan Mrtode Foam Mat Drying. Balai Pengkajian Teknologi Sumatera Barat, Sumatera Barat

23. Julaykha. 2014. Kacang Hijau. Ilmiah.um.ac.id/index.php/skripsi-tataboga/artikel. (diakses : 8 Maret 2016).

24. Krisnandi, 2013. Super Nutrisi Kelor. http://kelorina.com.( diakses : 9 Maret 2016).

25. Mohamad Fajar Daud, Esti R. Sadiyah, Endah Rismawati. 2015. Pengaruh Perbedaan Metode Ekstraksi Terhadap Aktivitas Antioksidan Ekstrak Etanol Daun Jambu Biji (psidium guajava L) Berdaging Buah Putih. Universitas Islam Bandung (UNISBA), Bandung.

26. Muchtadi, T. R., Sugiyono., Ayustaningwarno, F. 2013, Ilmu Pengetahuan Bahan Pangan. Alfabeta, Bandung.

27. Mulyati, N.D,. 1994. Mempelajari Pengaruh Metode Pemasakan Terhadap Stabilitas Karoten
Pada Beberapa Sayuran Hijau. Institut Pertanian Bogor,Bogor.

28. Muradmaulana, 2014. Manfaat Kacang Hijau dan Kandungan Gizinya. www.muradmaulana.com/2014/02/manfaatkacang-hijau-dan-kandungan.html. (diakses : 7 Maret 2016).

29. Musyair, 2014. Studi Pembuatan Minuman Bubuk Kacang Hijau (Phaseolus radiatus L) dan Bubuk Daun Katuk (Sauropus androgynus L). Univeristas Hasanuddin, Makasar.

30. Prasetyo, S dan Vicentius. 2005. Pengaruh Penambaan Tween 80, Dekstrin dan Minyak Kelapa Pada Pembuatan Kopi Instan Menggunakan Metode Pengeringan Busa. Jurnal Teknik Kimia Indonesia 4(3): 296-303.

31. Purnamasari Ratna. 2011. Pengaruh Jenis Pembusa Dan Suhu Pengeringan Pada Pembuatan Serbuk Pewarna Alami Dari Kulit Buah Naga Merah (Hylocereus polyhizus) Dengan Metode Foam Mat Drying. Universitas Pasundan Bandung, Bandung.

32. Qomad Dillah, Shohib, Ismail, Abdul Malik Hosyiyar Rohman, Yudha Pradipta Putra, Marisa Serawan. 2006. Pembuatan Susu KAcang Hijau Sebagai Alternatif Minuman Kesehatan. Institut Pertanian Bogor, Bogor.

33. Rahman Taufik, 2011. Pemanfaatan Kacang Hijau (Phaseolus raditus L) Menjadi Susu Kental manis Kacang Hijau. Universitas Islam Bandung (UNISBA), Bandung.

34. Sudarmadji.1989. Analisis Bahan pangan Dan Pertanian. Liberty Yogyakarta dan Universitas Pangan dan Gizi Universitas Gadjah Mada, Yogyakarta.

35. Triyono, Agus, Nurhaidar rahman, Yusuf Andriana. 2010. Pengaruh Proporsi Penambahan Air Pengekstraksi Dan Jumlah Bahan Penstabil Terhadap Karakteristik Susu Kacang Hijau (Phaseolus raditus,L,). Balai Besar Pengembangan Teknologi Tepat Guna - LIPI, Subang.

36. Wika Suka Pradana, Sri Kumalaningsih, Ika Astari Dewi. 2014. Pembuatan Bubuk Susu Kacang Hijau Instan Menggunakan Metode Foam Mat Drying. Universitas Brawijaya, Malang.

37. Zaidah Siti, 2011. Pengaruh Pencampuran Tepung Kacang Hijau (Vigna Radiata L) Dalam Pembuatan Cookises Terhadap Sifat Fisik, Sifat Organoleptik dan Kadar Proksimat. Universitas Respati Yogyakarta, Yogyakarta.

38. Zuhra Cut Fatimah, Juliati Br.Taringan, Herline Sitohang. 2008. Ativitas Antioksidan Senyawa Flavonoid Dari Daun Katuk. Universitas SumetraUtara. 